\section{Dangerous dealings}

\section{Alex Comfort}

Contamination: A Novel. By Chapman Pincher. Sidgwick \& Jackson: 1989. Pp.343. £12.95.

DR Wendy Payne, a microbiologist reluctantly involved in an (unauthorized) British germ-warfare laboratory, whose "effulgence of sex ...through no conscious effort on her part, could cause stirrings in the private parts of men across the proverbial crowded room", has discovered a bacterial clone which can digest silicon - including that contained in heat-sealed microchips. She is very appropriately murdered on page 1 of this novel after licking an envelope laced with botulinus toxin. The CIA attempt to smuggle a potentially damaging supply of the bacteria in a Star Wars simulator consigned to the Soviet Union: although this is the period of glasnost and détente, hardfaced GRU plotters, treacherous opponents of the arms race, and contemptible Members belonging to the No Hope Party (the loyal Opposition?) who ask questions about MI5 operations, are all in evidence, and the plot is enacted by the licenced paranoiacs of three nations for 343 pages.

Chapman Pincher's style of writing and his conception of fiction remind me a little of the imitators of the late Nat Gould, but Nat Gould knew a great deal about racing and his backgrounds were plausible. The alarming feature of this extravaganza, which prevents it from being funny, is that Mr Pincher professes to know a lot about the inaptly named Intelligence Community, and his professions might be true. $\mathrm{He}$ pictures it as a battery of loose cannon, accountable to nobody, riddled with double and treble agents, capable of any excesses, however hare-brained, and sharing Mr Pincher's rather nutty political opinions. Could he possibly be right?

With the example of Spycatcher before them and $\mathrm{Mr}$ Pincher's confirmation, scientists might well conclude that intelligence is an ingredient conspicuously lacking from this bunch, and that to hand any interesting finding to such morons under conditions of secrecy is simply not tolerable. I doubt if the author intended it in that way, but this book, for any reader who doesn't give up in exasperation, is one further powerful argument for a Freedom of Information Act. It is easy to disbelieve that there really are people who think and act like this, but the Pincher analysis has confirmation from another 'inside' source several degrees of magnitude up the literary scale, in Le Carré's The Russia House.
Even if it were better written, one couldn't recommend this novel as light entertainment to any scientific reader least of all to any scientific reader who on patriotic or grant-obtaining grounds has inadvisedly committed him or herself to work of 'national importance'. If the Manhattan Project team lived to regret their trust in government, anyone under- taking similar work today, in peacetime, might well be moved by this insight into Pincherism to write two letters - one of resignation, the other, in a plain unpoisoned envelope, to $\mathrm{Mr}$ Tam Dalyell MP, blowing the whistle. He or she would probably be right.

Alex Comfort is at The Windmill House, The Hill, Cranbrook, Kent TN17 3AA, UK.

\section{In the fast lane}

\section{John Treherne}

Cantor's Dllemma. By Carl Djerassi. Doubleday, New York: 1989. Pp.231. $\$ 18.95$. To be published in Britain next Spring by Macdonald.

CARL Djerassi can write - there is no doubt about that - which is why reading his novel is such a bruising experience. The narrative bounces along from one repellent character to another. They really are a ghastly bunch.

Take Celestine, for example. At the beginning of the book she seems a relatively innocent little thing. Yet before leaving high school she has been deflowered by the swimming coach and has received her marching orders from the chemistry teacher: "the union card for serious research is a Ph.D. Get it as quickly as possible". To obtain a "top academic position", young Celestine is told - before she even sets foot in a university - that she must infiltrate the old boys' network by doing postdoctoral work "with two different mentors at two different institutions". If things turn out well she will then have three men in universities pushing for her. This is all very necessary, for, she is assured, "Chemistry is still a man's world".

Thus counselled, the poor girl takes off for a six-year "combined B.S.-Ph.D. program" at Johns Hopkins. There she works frenetically to further her career, both in the classroom and on her back - it still being a man's world in chemistry - with a dirty old man on the faculty, Professor Graham Lufkin, world expert on insect pheromones and an opera buff. But Celestine knows what she is about ("she felt the quality of intercourse with him - intellectual as well as sexual - was far superior to what her male peers could offer"). They are all like that on the fast track in Cantor's Dilemma. Very sportingly for such a cad (he also gives seminars with suggestive titles such as "One-night Stands Among Insects", much to the delight of his prurient audiences), Lufkin eventually sends her to do her $\mathrm{PhD}$ research with Jean Ardley. Ardley (formerly "Yardley"; she knocked off the "Y" to get alphabetical priority in multiauthor papers) is another fast-tracker who has had her "tubes tied up" and who, Celestine suspects, was previously bedded by the dreadful Lufkin.

Celestine is next laid by Jeremiah (Jerry) Stafford, of whom she becomes quite fond (despite the fact that he at first lacks "the deft touch of Lufkin"). He is the research student of Professor I.C. Cantor, a big-shot molecular biologist with bushy hair, a large nose and very highly developed ambitions - which include winning the Nobel prize specifically by formulating a

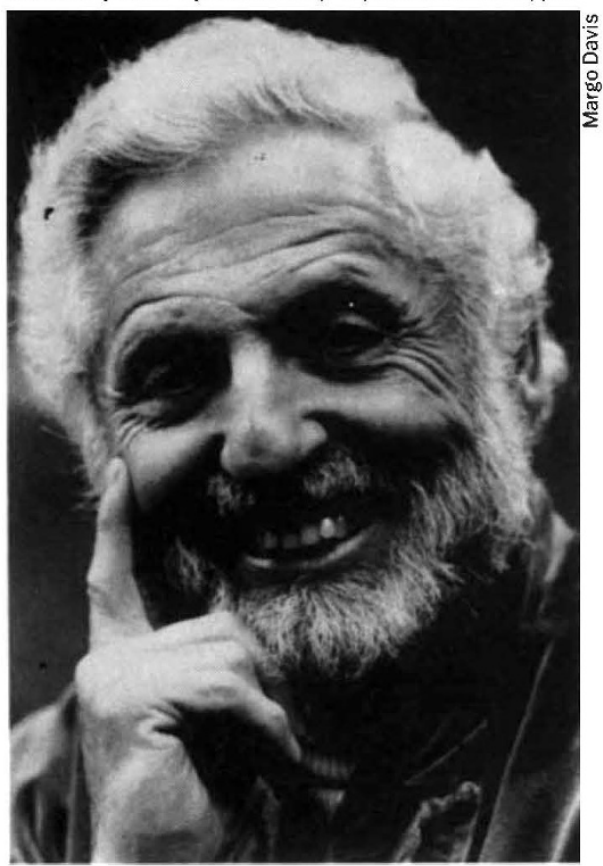

Djerassi — telling a tale

new theory of tumorigenesis. As Professor Djerassi puts it: "In the cancer field. . . a generalized theory of tumor production is Mount Everest or K-2. Only superstars climb such peaks, and even they use Sherpas. I. Cantor was such a superstar and Stafford became his Sherpa". - for a scientist at least - with his Patek Philippe watch, BMW sedan, silk necktie (worn even in the laboratory), gold Mont Blanc fountain pen, his valuable collection of erotic paintings and expert playing in a Boccherini quintet. Like everyone else in the book he is without a vestige of humour. It is in the quintet that he meets Celestine's Auntie Paula (who is pretty fancy herself - not only does she have expensive antiques and play the cello, but she makes some really helpful remarks about cunnilingus when I.C. shows her his
The superstar turns out to be a real dude 
erotic pictures).

Meantime, Sherpa Stafford is slaving away at hush-hush experiments to prove Cantor's cancer theory. These are so hush-hush and so exhausting that they drive Celestine to complain about his sexual inadequacies, as she soaps his nether regions, using that four-letter word which Ken Tynan - like Carl Djerassi did not shrink to use. Eventually, Stafford succeeds and all is set for the vital letter to Nature which eventually yields the "Nobel in medicine". But not before a lot of worry and unpleasantness about the inability of Kurt Krauss, I.C.'s nasty competitor at Harvard Medical School, to repeat poor Stafford's work. Had Jerry fiddled the results? We are not really sure even when Celestine is disturbed with another boyfriend - appropriately called Roger - to learn that Jerry is to share the Nobel prize with I.C. her Auntie Paula and they all have a wonderful time - pages of it - with both I.C. and Jerry spouting T.S. Eliot in their
Celestine goes along to Stockholm with

speeches and Jerry having a nice gossip with the Swedish Queen about how the Brits use their knives and forks and eat peas.

And that's about it really, apart from some reasonably happy endings - all neatly tied up - and a final bitter letter to I.C. from poor old Krauss, who is still as sick as a parrot about not getting his Nobel prize.

What, I wonder, were Professor Djerassi's motives in writing this book? Is he condoning what he portrays? Is he saying, look, this is how it is. What a smart lot we scientists are: pushy, clever, cutting corners (nudge, nudge), getting a bit on the side (snigger, snigger), swanking about our erotic pictures and Boccherini! If he is, then the hell with it. If, on the other hand, he is saying, look, this rat race is awful, then Cantor's Dilemma is a clever, if stomach-turning, way of portraying it. $\square$

John Treherne, novelist and scientist, died on 23 September. This rumbustious review was characteristic of the writer and the man.

\section{Ideal thinking}

\section{Steven Rose}

Russian Psychology: A Critical History. By David Joravsky. Basil Blackwell: 1989. Pp. 583. £45, \$34.95.

IMAGINE a book entitled American Psychology: A Critical History, the first third of which advances that history no further than 1917, the bulk of which follows events only to the early $1930 \mathrm{~s}$, and which devotes a mere 30 pages to the years since 1953 - years that have seen such a flowering of the neural and behavioural sciences, and the transformation of our understanding of brain and behaviour. That this disproportion does not seem wholly incongruous for a Western history of Soviet psychology is of course indicative of the extraordinary interest that the first 36 years of the tortured (and torturing) relationship of Soviet communism with science has held for political philosophers, historians and scientists alike. Nor would a history of American psychology of the period (unless of course written by Mr Leo Abse, MP, the recent biographer of Britain's present Prime Minister) be likely to find space for a psychological analysis of F.D. Roosevelt, as this book offers for Stalin. But it also reveals the limits of that interest, for Stalin's death in 1953 is precisely the midway point between October 1917 and the current era, and the second half of this period should surely be as relevant and subject to historical scrutiny as the first for what claims to be, as Joravsky's book does, a comprehensive account.
The superficial view of Soviet science under Stalin sees the period straightforwardly as one in which scientific data and theory were subordinated to political ideology, typified by the Lysenko episode in genetics, often regarded as a simple count misses the passionate concern of Marxism to see itself simultaneously as science and metascience, and the equally powerful determination of an impoverished and backward country to embrace and use science in its desperate push towards modernization. Equally, an unquestioning acceptance of the Western liberal view of science as neutral and above politics, philosophy or ideology misses the opportunity to see, in that Soviet experience, a mirror of some of the problems about the place and organization of science in our own society.

A number of Western scholars have tried to move beyond this simplistic view; the Lysenko affair has been reassessed by Levins and Lewontin, by Lecourt and by Joravsky himself, while Loren Graham's comprehensive Science and Philosophy in the Soviet Union has recently been revised and republished. Joravsky's earlier essay in this direction, Soviet Marxism and Natural Science, was for a long period after its appearance in 1961 the only book on the theme in English.

The development of Soviet psychology is of particular interest. First, psychology had strong roots in pre-revolutionary Russia, stretching back through Pavlov to Sechenov. Second, the subject matter of psychology has profound bearing on theories of human nature and society, and hence a fortiori on Marxism. Third, the theoretical battle between materialism reciprocal of Nazi eugenics. Such an ac- and dualism, between reductionism and dialectics, which in many areas of science is masked or confined to the philosophers, has been and remains a vital issue of methodology and scientific practice for research in psychology and neurobiology in the West as well as the East. Finally, the vast experiment in social engineering in the Soviet Union during the first half of its post-revolutionary history was directed to the creation of "the new socialist man [sic]", and one might well have expected that psychologists would find themselves mobilized to this task.

Thus, from the $1920 \mathrm{~s}$ on, Soviet neurophysiologists, psychologists and philosophers struggled to develop an adequate theory of the dialectic of brain and society in the production of mind, and an adequate practice of pedology (educational science) and psychotechnics based upon that theory. This struggle with some of the deepest conceptual and methodological problems with which science has to cope, produced responses ranging from the hard-line physiological materialism of Pavlov almost until his last days, through the pioneering work on the social production of mind by the polymath Vygotsky and the later development of neuropsychology by Luria. In the next generation it produced Rubinshtein's activity theory, Anokhin's functional systems approach, the work of Beritashvili, Leontiev and Orbeli, as well as a strong school of functional neurochemistry.

And of course, the work of nearly all of these scientists was punctuated by endless crises, from the desperate economic situation and famine of the early years (to be repeated during the 'Great Patriotic War'), through the increasing tendency to solve scientific disputes by administrative fiat - with all the dread consequences that that entailed - from the 1930 s to well beyond the death of Stalin. The debates in psychology seem not to have been quite so literally life-and-death affairs as they were in genetics, although Joravsky lists many victims of the Gulag. True, after 1945 Pavlov was for a time elevated to stardom within Stalin's pantheon, and recantation was forced upon those of his pupils and disciples whose greater understanding of brain physiology and psychology (to say nothing of their better Marxism) led them to deviate from the line of their late master. Even so, the debates in the 'Pavlov sessions' for psychologists, physiologists and psychiatrists in 1950,1951 and 1952 seem much less staged and more open than the notorious 1948 session of the Agricultural Academy which saw the destruction of genetics and the apotheosis of Lysenko.

Just why this should be so would seem to be a question of some significance perhaps it was because of the stronger research and philosophical traditions of Soviet psychology and physiology; 